\title{
Denise Schittine - Ler e escrever no escuro: a literatura através da cegueira
}

Rio de Janeiro: Paz e Terra, 2016

Renata Magdaleno ${ }^{1}$

Muitas pesquisas acadêmicas se misturam com a vida pessoal dos pesquisadores. Não se trata apenas do momento em que, ao escrever uma tese ou dissertação, a cabeça passa a estar tão focada que tudo se transforma em uma referência. São históricos familiares e experiências pessoais que influenciam na escolha dos temas estudados. Trajetórias de pesquisa que transparecem nas entrelinhas do texto final. Esse é caso de Ler e escrever no escuro: a literatura através da cegueira (2016), tese de doutorado que a pesquisadora Denise Schittine transformou em livro e publicou pela editora Paz \& Terra.

Foi a ansiedade diante de um histórico de doença ocular na família que a fez escolher o tema. Os livros, seus companheiros fiéis, presentes mesmo nos momentos de maior solidão, podem faltar na idade avançada, se a autora também tiver a mesma sorte dos parentes. O temor fez Schittine explorar a relação entre escrita e cegueira nos mais diferentes aspectos, dos detalhes históricos, aos elementos sensoriais. Para a autora, "a leitura, principalmente do texto literário, não é apenas decodificação de informação, mas um ato responsável por gerar prazer: cada uma das palavras lidas reflete no corpo do leitor, em seus ritmos sanguíneos, seus batimentos cardíacos, sua história pessoal" (Schittine, 2016, p. 27).

Do momento da recepção aos hábitos de leitura - "Fazer um chá, limpar os óculos, regular a luz do abajur e afundar-se confortavelmente numa poltrona com as pernas estendidas, esperando que o silêncio venha e, só então, abrir o livro (Schittine, 2016, p. 65) -, todo o processo é investigado, com o intuito de refletir sobre o quanto cada etapa é imprescindível. Como substituí-las no momento em que a visão falta? Como trocar a voz interna de cada leitor pela de um ledor, alguém que empresta sua entonação e ritmo para o outro?

Nem sempre questões como essas foram vistas como um problema. Ler não foi, ao longo da história, necessariamente, um ato íntimo e

${ }^{1}$ Doutora em literatura brasileira e pós-doutoranda, com bolsa da Faperj, na Universidade do Estado do Rio de Janeiro (Uerj), Rio de Janeiro, RJ, Brasil. E-mail: renata.magdaleno@ gmail.com 
solitário. No passado eram comuns as leituras estarem associadas a encontros, onde um leitor em voz alta contava histórias. "As leituras públicas e informais eram constantes no século XVII. Faziam parte das reuniões entre amigos ou famílias que, portanto, eram mais descontraídas e permitiam uma maior liberdade ao ledor" (Schittine, 2016, p. 129). Vários escritores também costumavam realizar leituras, testando a reação do receptor, antes que suas obras ganhassem o público, caso, por exemplo, de Charles Dickens.

As tecnologias que foram surgindo ao longo do tempo também interferiram no processo de escrita e leitura. Antes que a invenção de Gutenberg fizesse com que os textos se disseminassem e ganhassem divulgação em grande escala, antes que os livros se transformassem em exemplares compactos e fáceis de deslocar, a solução era escutar àquele que tinha acesso a enormes aparatos difíceis de manusear, como os códices, o precursor do livro moderno.

Nesse tema, é possível também associar o estudo de Schittine com seu livro anterior: Blog: comunicação e escrita intima na internet (2004). A possibilidade de postar na rede os escritos antes que eles sejam publicados por qualquer editora torna novamente esse um processo público. Por conta da tecnologia, o leitor passa a ter acesso ao processo de escrita, às etapas do texto antes que ele fique pronto por completo. Em entrevista para a revista eletrônica Caju, no início de 2017, a autora confirma:

A escrita da internet colocou o autor em novas lentes. Ele escreve agora, mas com a opinião do leitor por perto, os comentários, as observações. Ele escreve um hipertexto, o que faz com que algumas coisas se percam na memória do computador e o que faz com que, de uma forma meio sarcástica, voltemos a ler como os antigos liam os rolos, antes de códex. As posturas de escrita e leitura mudam completamente: o texto começa a passar por várias mãos, mesmo quando sai do autor indo direto para a editora e é cortado, preparado, reduzido, aumentado, repensado por uma, duas ou mais cabeças (Schittine, 2017, s.p.).

Mas, apesar das possibilidades tecnológicas, a leitura e a escrita ainda são vistas, na atualidade, como processos íntimos, solitários. É como se a publicação das etapas de escrita, dos rascunhos do livro em processo em blogs se associasse mais a um espetáculo, uma performance literária, capaz de divulgar a obra e seu autor. Cada leitor tem uma voz interior, que o acompanha ao longo das linhas. Uma voz que precisa ser substituída pela 
do ledor, a pessoa escolhida para perpetuar a relação entre o leitor sem visão e os livros, quando quem não enxerga não possui intimidade com o alfabeto em braile. No estudo de Schittine essa relação entre leitor e ledor é privilegiada, porque a autora detectou que quando a falta de visão atingia a pessoa com idade mais avançada o aprendizado em braile era muito penoso e um parente íntimo costuma ser a escolha mais comum para perpetuar essa relação com o mundo dos livros. Foi o caso de dois escritores-cegos consagrados: o argentino Jorge Luis Borges e o brasileiro João Cabral de Melo Neto.

Como Borges e João Cabral lidaram com a perda da visão, como conseguiram (ou não) aliar escrita e leitura com a escuridão sem fim? A parte mais saborosa do estudo está na pesquisa minuciosa da trajetória desses grandes autores. Duas trajetórias semelhantes e dois desfechos tão distintos. Enquanto Borges consegue criar artifícios para continuar acessando a escrita e a literatura, João Cabral afunda em uma escura depressão de onde não encontra esperança ou saída.

Parte da pesquisa para o livro foi realizada na Argentina, seguindo os passos de Borges, entrevistando pesquisadores; tentando acessar María Kodama, a viúva do escritor, ou encontrar a biblioteca do autor, mencionada diversas vezes em seus escritos. Na já mencionada entrevista, publicada logo após o lançamento do livro, Schittine conta que tentou diversas vezes marcar uma entrevista com a viúva de Borges, através da Fundación Borges, sempre recebendo um não como resposta. Um dia, enquanto estava em Buenos Aires pesquisando, resolveu aparecer de surpresa e perguntar por Kodama. Uma secretária solícita a levou diretamente para o escritório da esposa do escritor.

Não fui embora sem antes descobrir porque eu tinha conseguido que a secretária me abrisse as portas: a sobrinha de Kodama iria visitar a tia naquele dia. E, em sua defesa, a assistente dizia que eu era "igual" a ela. Isso me valeu o apelido de "sobriña Kodama", festejado por todos os amigos argentinos (Schittine, 2017, s.p.).

Borges perdeu a visão quando já era um escritor e leitor maduro e, como Homero, detentor de uma memória invejável, recheada de mitos, lendas, versos e histórias. Toda sua trajetória foi rodeada pelos livros, desde a infância em Buenos Aires - marcada pela biblioteca do pai, com títulos ingleses, que, para o menino, pareciam intermináveis - até o período em que a família viveu na Europa, em busca de cura para a 
cegueira do pai (na família de Borges a doença ocular também era uma maldição temida pelos descendentes). Todo um mundo a ser explorado.

Havia toda uma linhagem de escritores na família de Borges que marcou também sua escolha pelos livros. O pai tinha a esperança de que o filho alcançasse a fama nas letras que ele e o avô não tinham conseguido. E o autor começou copiando o estilo dos escritores que admirava até se tornar uma das maiores influências literárias da região.

Quando a cegueira o alcançou (e para ele a falta de visão tinha um aspecto peculiar, como uma espécie de branco infinito), tinha assumido o cargo de diretor da Biblioteca Nacional e estava como sempre gostou, rodeado de livros. Para continuar suas leituras, recorreu primeiramente à mãe como ledora, numa espécie de volta à infância. A mesma voz que embalava as histórias para um menino ainda não alfabetizado volta na idade avançada, para manter a conexão do escritor com a biblioteca que o acompanhou ao longo da vida.

$\mathrm{Na}$ escrita também voltou ao gênero do início da carreira, a poesia. Criava e pedia para que escrevessem cada uma das palavras que guardara na memória, frisando a pontuação, e que lessem inúmeras vezes para que ele testasse se estavam de acordo. "Ele refazia o caminho que havia iniciado no princípio de sua vida, começara fazendo poesia e assim terminara, como num ciclo" (Schittine, 2016, p. 309).

João Cabral de Melo Neto não conseguiu se adaptar como Borges. O autor sofreu de "degenerescência macula" e, a partir de 1986, quando tinha 66 anos, teve uma perda gradativa de visão. Ele não chegou a sofrer a cegueira total, mas a doença, que deforma as linhas e impossibilita a leitura, o afastou do mundo dos livros. Seu processo de escrita era demasiadamente visual. Em várias entrevistas e poemas Cabral afirmou que não tinha uma relação sonora com os textos que produzia, muito pelo contrário, seu trabalho era de artesão, e as artes visuais eram referências constantes em seus escritos.

Ezra Pound diz que há três tipos de poesia: a fanopeia, que apresenta uma realidade visual ou visualizável - como exemplos: Cesário Verde, Lorca e até Dante -; a melopeia, de sugestão auditiva, como a música, e de que poderemos ter exemplos em Verlaine e Eugênio de Castro; e a logopeia, poesia que transmite uma ideia de que achamos um modelo nos sonetos de Camões. [...] Ora, a poesia portuguesa e a brasileira são preponderantemente melopeia e logopeia. [...] Eu sou preponderantemente de uma poesia fanopeia (Cabral apud Schittine, 2016, p. 385). 
Como leitor-ouvinte, era impaciente e irritadiço. Como escritor, a construção artesanal de seus textos pedia a ajuda dos olhos, para que fossem vistos estampados na página. A perda da visão acabou com sua carreira de escritor, acabou com o prazer da leitura. Restou amargura e depressão.

O livro de Schittine traz ao leitor que nunca teve acesso a esse campo de estudo conclusões inesperadas. Revela como os processos de escrita e leitura foram culturalmente construídos ao longo do tempo, afetados também por transformações tecnológicas que provocaram, ao longo do tempo, mudanças em toda a sociedade. Revela, ainda, que a relação que construímos com os livros, além de sofrerem influências culturais, também são pessoais. Cada leitor cria seus próprios rituais. Cada escritor idem. E a sobrevivência de tais práticas diante da cegueira está diretamente ligada a essa relação.

\section{Referências}

SCHITTINE, Denise (2004). Blog: comunicação e escrita íntima na internet. Rio de Janeiro: Record.

SCHITTINE, Denise (2016). Ler e escrever no escuro: a literatura através da cegueira. Rio de Janeiro: Paz\&Terra.

SCHITTINE, Denise (2017). Ensaio sobre a cegueira. Entrevista a Renata Magdaleno. Caju: Arte, Cultura, Criatividade, Rio de Janeiro, 10 jan. On-line. Disponível em: <http://revistacaju.com.br/2017/01/10/ensaio-sobre-acegueira/>. Acesso em: 10 mar. 2017.

Recebido em 4 de abril de 2017.

Aprovado em 20 de junho de 2017. 